\title{
TESTICULAR HYPERTHERMIC SHOCKS AND THE BOUNDARY TISSUE OF THE SEMINIFEROUS TUBULES IN RATS
}

\author{
K. G. KANWAR, S. R. BAWA AND P. K. SINGAL \\ Department of Biophysics, Panjab University, Chandigarh, India
}

(Received 26th March 1974)

Changes occurring in the wall or boundary tissue (Lacy \& Rotblat, 1960) of the seminiferous tubules following damage of the testis have been reported by several workers (Lacy \& Rotblat, 1960; Turpeinen, Turpeinen \& Talanti, 1962; Lacy, 1964; Schöffling, 1965; Idanpaan-Heikkila, 1966). Though hyperthermic sensitivity of the germinal epithelium of the mammalian scrotal testes has been well documented (Collins \& Lacy, 1969), response of the boundary tissue of seminiferous tubules to hyperthermia has not been properly studied. The brief comments of Turpeinen et al. (1962) and Idanpaan-Heikkila (1966) pertaining to the structure and histochemical make-up of the boundary tissue following testicular hyperthermic shock, however, are suggestive of its altered physiology.

Sexually mature male albino rats, each weighing 200 to $250 \mathrm{~g}$, were anaesthetized with Nembutal $(5 \mathrm{mg} / 100 \mathrm{~g}$ body wt) and were allotted to six groups, each of which included an average of eight rats. The control rats, composing Group I, were not subjected to hyperthermic shock. The pelvic region of the rats in Groups II to VI were immersed up to the penis level for $20 \mathrm{~min}$ in a water-bath maintained at $43 \cdot 5^{\circ} \mathrm{C}$. The heat-treated rats were killed after $3,7,14,21$ and 42 days respectively.

Various histochemical techniques were used for the localization of lipids (Baker, 1944), carbohydrates (Hotchkiss, 1948; Himes \& Moriber, 1956), and alkaline (Gomori, 1946) and acid phosphatases (Gomori, 1950) in the tissues of both the control and the experimental rats.

For the identification of lipids, small pieces of tissue were fixed in formaldehyde-calcium, post-chromed for $18 \mathrm{hr}$ at room temperature and for $24 \mathrm{hr}$ at $60^{\circ} \mathrm{C}$, embedded in gelatine and finally coloured with Sudan black B, essentially as described by Baker (1944).

For the detection of carbohydrates, the periodic acid-Schiff (PAS) technique was generally employed on paraffin-wax embedded sections of material fixed in Zenker's fluid (see Baker, 1945). For PAS, the sections were oxidized in $0.5 \%$ aqueous periodic acid for $5 \mathrm{~min}$, followed by treatment with Schiff's reagent (Barger \& DeLamater, 1948). To assess the PAS results, the technique of Himes \& Moriber (1956) which simultaneously stains polysaccharides, DNA and proteins was also tried on Zenker-fixed material.

For cytochemical localization of acid and alkaline phosphatases, small 
pieces of tissue were fixed for $2 \mathrm{hr}$ in $10 \%$ formalin chilled at $4^{\circ} \mathrm{C}$ and the tissue was then embedded in soft paraffin (m.p. $52^{\circ} \mathrm{C}$ ).

For acid phosphatases, sections from which the paraffin had been removed were incubated for $30 \mathrm{~min}$ to $2 \mathrm{hr}$ in freshly prepared $0.01 \mathrm{M}$-sodium $\beta$-glycerophosphate in $0.05 \mathrm{~m}$-acetate buffer ( $\mathrm{pH} \mathrm{5.0)}$ ) containing $0.004 \mathrm{M}$-lead nitrate, and were washed briefly in distilled water. The sections were then immersed in dilute ammonium sulphide for 1 to $2 \mathrm{~min}$, washed and mounted in glycerine jelly (see Gomori, 1950). For localizing alkaline phosphatase, the sections were immersed for 2 to $6 \mathrm{hr}$ at $37^{\circ} \mathrm{C}$ in incubating medium $(10 \mathrm{ml} 3 \%$ sodium $\beta$-glycerophosphate; $10 \mathrm{ml} 2 \%$ sodium diethyl barbiturate; $20 \mathrm{ml} 2 \%$ calcium chloride; $1 \mathrm{ml} 5 \%$ magnesium sulphate; $5 \mathrm{ml}$ distilled water). After rinsing in running water, the sections were treated for 3 to $5 \mathrm{~min}$ in $2 \%$ cobalt nitrate, rewashed in distilled water, exposed to a dilute solution of yellow ammonium sulphide for 1 to $2 \mathrm{~min}$, rewashed and finally mounted (see Gomori, 1964). The presence of acid and alkaline phosphatases in the sections was indicated by a black or brownish-black precipitate of lead sulphide.

For measuring the thickness of the boundary tissue, micrometer scales were used.

Following heat treatment, there was a gradual increase in the thickness of the boundary tissue from $1.4 \pm 0.20 \mu \mathrm{m}$ found in the control Group-I rats to a maximum of $5 \cdot 25 \pm 0 \cdot 17 \mu \mathrm{m}$ in the most severely damaged testes of the animals of Group V (see Table 1). In Group-V rats, the boundary tissue was very thick and three (Pl. 1, Fig. 1) of the four constituent layers described by Lacy \& Rotblat (1960) were visible. Cytoplasmic projections from the cells of the innermost layer of the boundary tissue were seen to extend into the spermatogonial population (Pl. 1, Fig. 2). In certain heavily damaged tubules, especially in Group-V rats, the boundary tissue was seen to be detached from the germinal epithelium and infolded (Pl. 1, Figs 3 and 5).

During the recovery phase, shown by the rats in Group VI, the boundary tissue regained the smooth contour (Pl. 1, Fig. 4) which was characteristic of the tissue in the untreated rats (PI. 1, Fig. 6).

\section{EXPLANATION OF PLATE 1}

Fig. 1. Group-V rat 21 days after heat treatment. Portion of a seminiferous tubule showing three layers of the boundary tissue- a nuclear layer is visible between the two noncellular layers of the ground substance. Note the severe damage in the tubule. Zenker/ PAS-Delafield haematoxylin. $\times 1167$.

Fig. 2. Group-V rat 21 days after heat treatment. The boundary tissue shows cytoplasmic projections into the spermatogonial layer. Zenker/PAS. $\times 1167$.

Fig. 3. Group-V rat 21 days after heat treatment. The folding of the boundary tissue and its detachment from the germinal epithelium are clearly seen. Zenker/PAS. $\times 467$.

Fig. 4. Group-VI rat 42 days after heat treatment. Note the smooth contour of the boundary tissue and the recovery of the seminiferous epithelium. Zenker/Himes and Moriber. $\times 467$.

FIG. 5. Group-IV rat 14 days after heat treatment. Intense alkaline phosphatase activity is seen in the boundary tissue and in the walls of the blood capillaries in the interstitium. Formalin/Gomori technique. $\times 117$.

Fig. 6. Group-I control rat. Note the normal undamaged seminiferous tubule with smooth, PAS-positive boundary tissue; the blood capillary walls also show the reaction. Zenker/ PAS-Delafield haematoxylin. $\times 234$. 


\section{PLATE 1}

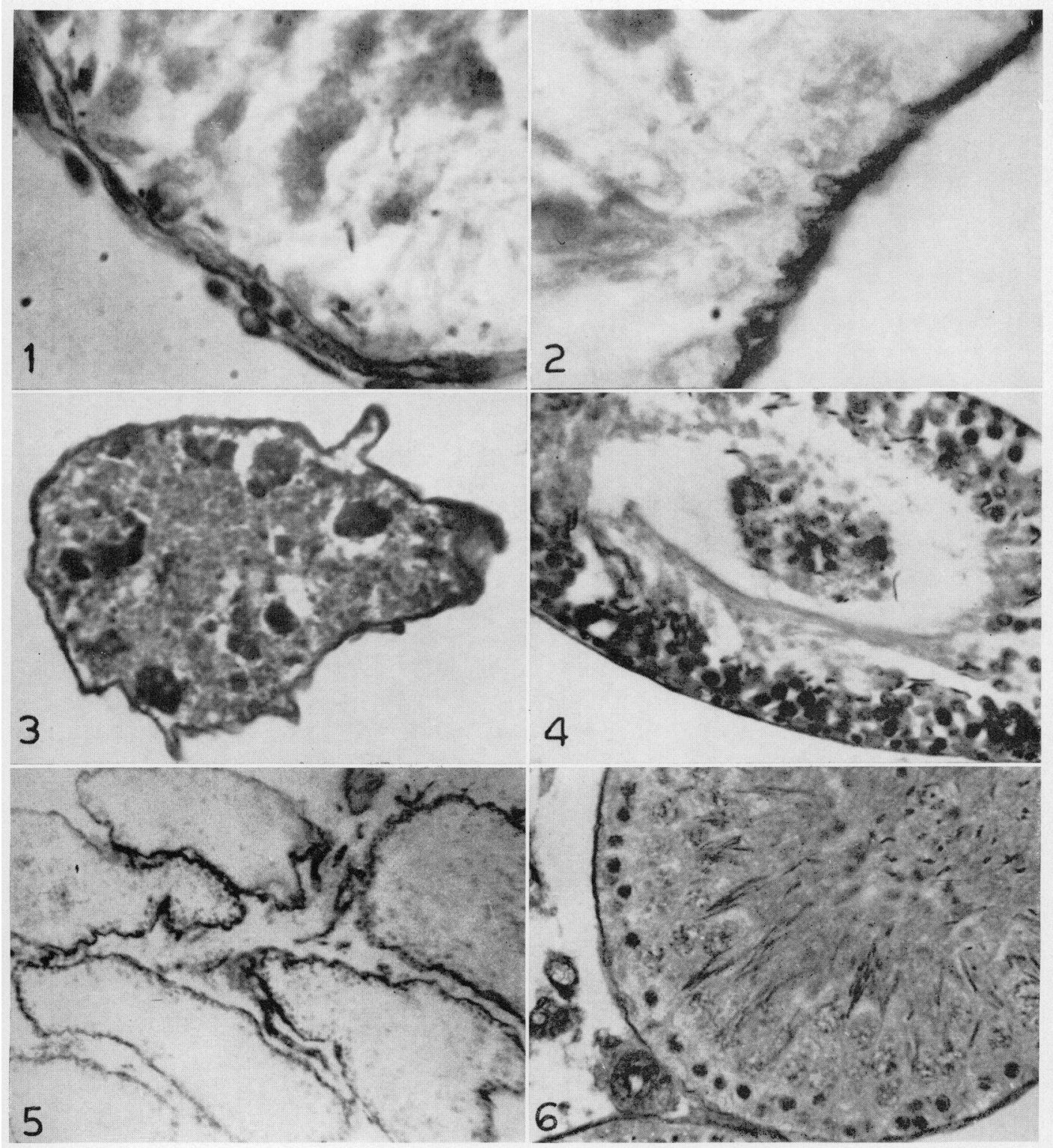

(Facing p. 202) 
Testicular hyperthermic shocks in rats

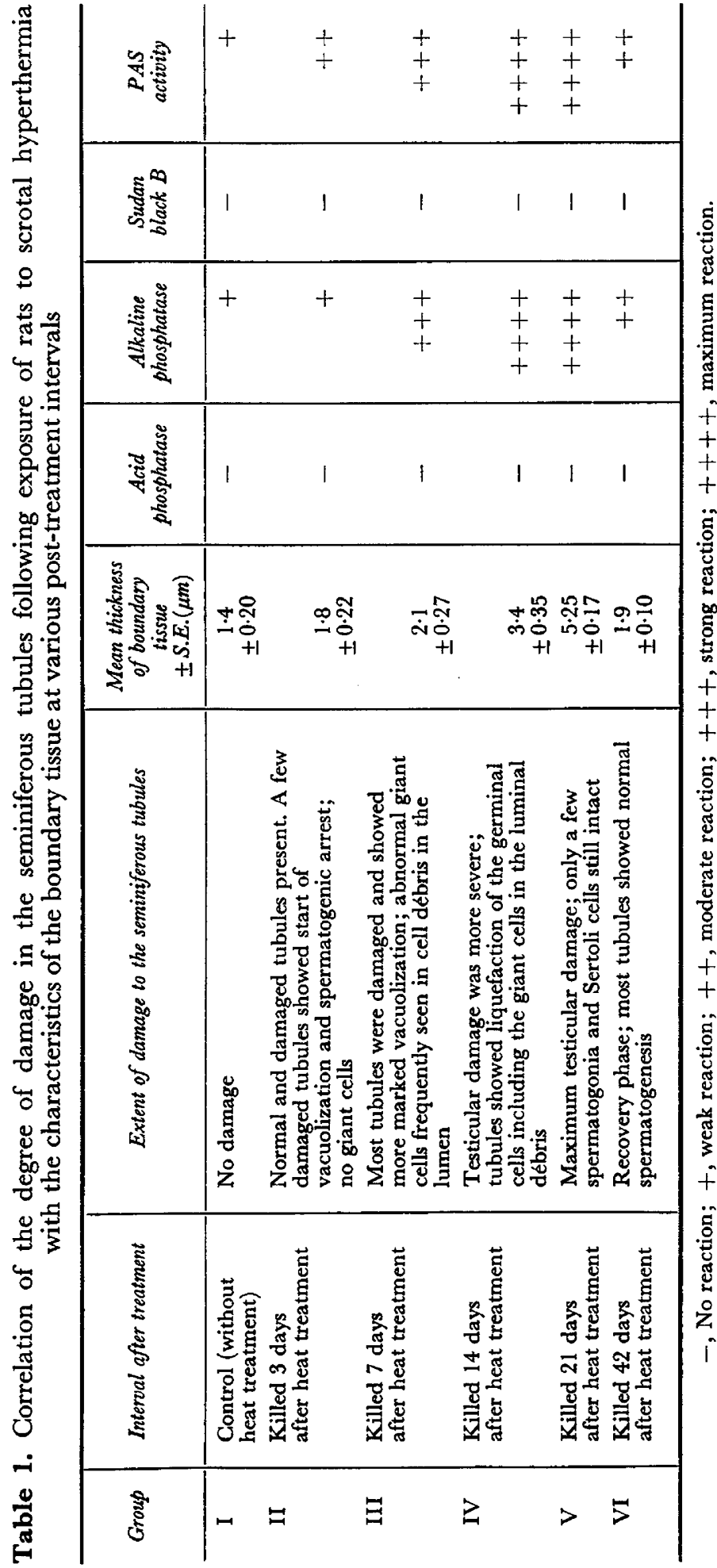


The boundary tissue in the rats of Groups II to V were increasingly PASpositive and showed a progressive increase in alkaline phosphatase activity. Neither acid phosphatase nor lipids could be demonstrated histochemically in the boundary tissue of the seminiferous tubules in the experimental and control animals.

During the recovery phase, all the changes in the boundary tissue showed a tendency to return to normal (Table 1).

The present studies reveal that the progressive morphological and histochemical changes in the boundary tissue are directly related to the extent of damage in the seminiferous tubules. Increased PAS-positive staining of the boundary tissue was always accompanied by increased alkaline phosphatase activity (Table 1), and the same was true of the blood vessels. The walls of blood capillaries in the interstitium showed intense PAS-positive staining and alkaline phosphatase activity (Pl. 1, Fig. 5) in the heat-treated testes, and again the activity was directly related to the extent of damage in the seminiferous tubules.

The boundary tissue not only supplies a base upon which cells grow, differentiate and develop but it is also physiologically active, admitting nutritive and excreting waste materials. The active involvement of the boundary tissue is further confirmed by the fact that histochemically it behaves more or less like the walls of the testicular blood vessels. It seems probable that the increased PAS and alkaline phosphatase activity of the boundary tissue is synchronized with its increased permeability. The structural complexities which the boundary tissue develops during testicular malfunctioning, therefore, are physiologically meaningful and suggestive of the altered physiology of this tissue.

\section{REFERENCES}

BAKER, J. R. (1944) The structural and chemical composition of the Golgi elements. Q. $\mathcal{f l}$ microsc. Sci. $85,1$.

BAKER, J. R. (1945) Cytological Techniques. Methuen, London.

Barger, J. D. \& DeLamater, E. D. (1948) Science, N.Y. 108, 121. (Gited in Pearse, 1960.)

Collins, P. \& LACY, D. (1969) Studies on the structure and function of mammalian testis. II. Cytological and histochemical observations on the rat after single exposure to heat applied for different lengths of time. Proc. R. Soc. B, 172, 17.

Gomori, G. (1946) Am. J. clin. Path. 16, 177. (Cited in Pearse, 1960.)

GomoRI, G. (1950) An improved histochemical technique for acid phosphatase. Stain Technol. 25, 81.

Gomori, G. (1964) Microscopic Histochemistry: Principles and Practice. University of Chicago Press, Chicago.

Himes, M. \& Moriber, L. (1956) A triple stain for deoxyribonucleic acid, polysaccharides and proteins. Stain. Technol. 31, 67.

Hoтchкiss, R. D. (1948) A microchemical reaction resulting in the staining of polysaccharide structures in fixed tissue preparations. Archs Biochem. 16, 131.

IDANPAAN-HEIKKILA, P. (1966) Effect of local heat in vivo on the fine structure of the basement membrane and the Sertoli cells of the rat testis. Fert. Steril. 17, 689.

LACY, D. (1964) Comparison of effects produced by high doses of ionizing radiation and oestrogenic hormone on the seminiferous tubules of rat testis. In Effects of Ionizing Radiation on the Reproductive Systems, pp. 189-212. Eds. W. D. Garlson and F. X. Gassner. Pergamon Press, Oxford.

LACY, D. \& Rotblat, J. (1960) Study of normal and irradiated boundary tissue of the seminiferous tubules of the rat. Expl Cell Res. 21, 49.

Pearse, A. G. E. (1960) Histochemistry: Theoretical and Applied. Little Brown \& Co., Boston.

SchöfFling, K. (1965) On the nature and treatment of diabetes. Eds. B. S. Leibel and G. A. Wrenshall. Excerpta Medica Foundation, New York.

Turpeinen, P., Turpeinen, O. \& Talanti, S. (1962) Effect of local heat in vivo on hyaluronidase, succinic dehydrogenase and phosphatases of the rat testis. Endocrinology, 70, 731. 